Sławomir Kamosiński

Kazimierz Wielki University in Bydgoszcz

Faculty of Humanities

e-mail: slawomirkamosinski@ukw.edu.pl

\title{
Praca jako obowiązek a praca jako źródło satysfakcji Studium historyczne roli i znaczenia pracy $w$ dziejach Polski (po 1945 roku)
}

\section{Work as a Duty versus Work as Source of Satisfaction. Historical Study of the Role and Importance of the Work in Polish History (After 1945)}

The paper presents an analysis of the ethical, political and economic aspects of human work within two Polish historical periods - the years of the People's Republic of Poland and after 1989. The starting point for the analysis was the assumption that every time period, each age, leaves a mark on man's work.

Analysis of the People's Republic of Poland period gives an opportunity to consider human work understood as a duty and right of every human guaranteed by the Constitution of 1952. Questioning the principles ruling the labour market by the ideologists of the People's Republic of Poland and, as a consequence, the politicization of labour, resulted in the collapse of the work ethic. Work, as it was at that time a commonly available good, lost its value, regarded as the source of life satisfaction, and thus became ridiculed.

After 1989, in relation to the de-politicization of the Polish labour market, the employee became active in searching for a job. The phenomenon of unemployment resulted in competition on the labour market and the employer was thus given the opportunity to freely select a group of employees. As a result, the employer became a distributor of a 'rare commodity.' That, in turn, led to the situation where the approach of employers towards employees turned into the employer's diktat. It is the employer who determines the conditions of employment, standards of work and place of work. A lack of alternative that many employees face often makes them accept the dictated conditions of work. What is more, in Poland we deal with the insufficiently developed participation of employees in managing the enterprises, which is an effect of breaking off the bilateral dependency of employee and employer. 
Keywords: human work, labour market, work ethic, employee participation in managing enterprises, bilateral dependency of employers and employees

JEL Classification: N34, P31

W pocie więc oblicza twego będziesz musiał zdobywać pożywienie Pismo Święte Starego i Nowego Testamentu, Rdz. 3, 17, 19

\section{Uwagi wstępne}

W niniejszym artykule, mającym charakter studium historycznego, poddano analizie pracę człowieka w dwóch okresach historii Polski: latach Polski Ludowej oraz w okresie po 1989 roku. Punktem wyjścia było przyjęcie założenia, że każda epoka odciska swoje piętno na pracy człowieka.

Analiza okresu Polski Ludowej daje możliwość zwrócenia uwagi na pracę człowieka jako na jego obowiązek i prawo, które gwarantowała mu Konstytucja z 1952 roku. Podważenie przez ideologów Polski Ludowej zasad rządzących rynkiem pracy, i w konsekwencji upolitycznienie pracy, stało się przyczyną upadku etyki pracy. Praca, stając się w tym okresie, dobrem powszechnie dostępnym, utraciła wartość postrzeganą w kategoriach źródła satysfakcji życiowej, a stała się przedmiotem wielu dowcipów.

Po 1989 roku, w związku z odpolitycznieniem w Polsce rynku pracy, pracobiorca stał się aktywny w poszukiwaniu pracy. Zjawisko bezrobocia spowodowało konkurencję na rynku pracy, a pracodawca zyskał możliwość swobodnego doboru zespołu pracobiorców. Stał się on dystrybutorem „dobra rzadkiego” i w konsekwencji postawa wielu pracodawców wobec pracobiorców przybrała charakter dyktatu pracodawcy. On ustala warunki zatrudnienia, normy pracy, miejsce pracy. Brak alternatywy, który dotyka wielu pracobiorców, zmusza ich często do akceptacji dyktowanych warunków pracy. W Polsce obserwuje się niedostatecznie rozwiniętą partycypację pracowników w zarządzaniu przedsiębiorstwem. Jest to z pewnością następstwo zerwania dwustronnej zależności pracobiorcy od pracodawcy.

\section{Praca w Polsce Ludowej}

Polska Zjednoczona Partia Robotnicza, która uzurpowała sobie prawo do wyłącznej reprezentacji robotników, a jako partia rządząca zapewniła sobie nadzór nad środkami produkcji, organizacją produkcji i projektowaniem rozwoju gospodarczego kraju, zapewniała sobie przy tej okazji pełną kontrolę nad pracownikiem i pracą przez niego wykonywaną. Przepis Konstytucji Polskiej Rzeczypospolitej Ludowej 
z 1952 roku stanowił, że Praca jest prawem, obowiazkiem i sprawa honoru każdego obywatela oraz to, że: Obywatele Polskiej Rzeczypospolitej Ludowej maja prawo do pracy, to znaczy prawo do zatrudnienia za wynagrodzeniem wedtug ilości i jakości pracy ${ }^{1}$. Podążając $\mathrm{w}$ ślad za tym przepisem przyjęto ideologiczne założenie o likwidacji bezrobocia i polityce pełnego zatrudnienia. To osiągnięcie w polityce zatrudnienia miało być kamieniem milowym sukcesu modernizacyjnego Polski Ludowej. W praktyce wpłynęło ono wydatnie na kształt rynku pracy, który w zasadzie przestał istnieć. Pierwszą konsekwencją ingerencji ideologii w rynek pracy i reguły nim rządzące było to, że bezrobocie przeniesione zostało do przedsiębiorstw. Wygenerowano w ten sposób zjawisko bezrobocia w miejscu pracy. Stopa ukrytego bezrobocia w Polsce Ludowej, według obliczeń Pawła Glikmana, w 1980 roku wynosiła ogółem 26,7\%, a w przemyśle 29,7\%, natomiast w 1989 roku kształtowała się ona na poziomie $20,9 \%$, zaś w sektorze przemysłowym $-29,1 \%{ }^{2}$. Według innych źródeł ukryte bezrobocie w przedsiębiorstwach szacowano na około $33 \%$ zatrudnionych ${ }^{3}$.

Odczuwalnym następstwem braku możliwości efektywnego zagospodarowania przez państwowego pracodawcę zatrudnionych w przedsiębiorstwie na tzw. etatach pracowników było to, że praca gwarantowana przez państwo stała się produktem mało atrakcyjnym dla wielu obywateli Polski Ludowej. Była ona zapewne jedynym produktem (towarem), który w gospodarce cierpiącej na chroniczne niedobory, był powszechnie dostępny. Ofert pracy było więcej niż osób gotowych ją podjąć, popyt na pracę przewyższał podaż. Ta sytuacja sprawiła, że empirycznie przekonywano się o tym, że etyka pracy uległa dewaluacji, a produktywność pracowników była bardzo niska.

Znalezienie pracy w Polsce Ludowej nie było trudne, nie wymagało podjęcia jakiś szczególnych zabiegów. W następstwie tego faktu zanikało u pracobiorców, tych którzy rozpoczynali pracę, a także tych osób, które już pracowały, tak rozpowszechnione w krajach kapitalistycznych planowanie w kategoriach jednostkowych strategii rozwoju ${ }^{4}$. To często praca upominała się o człowieka i ona go szukała, a paradoksem było to, że $w$ okresach zaostrzenia walki z pasożytnictwem społecznym więcej wysiłku i zabiegów wymagało uchylanie się od pracy niż jej znale$z_{i e n i e}{ }^{5}$. W tak komfortowej sytuacji dla pracobiorcy pretekstem do porzucenia pracy było nawet ciepłe lato i pojawiająca się w związku ze wspaniałą aurą potrzeba wydłużenia urlopu. Zjawisko to opisano np. w odniesieniu do Przędzalni Wełny

\footnotetext{
${ }^{1}$ Konstytucja Polskiej Rzeczypospolitej Ludowej uchwalona przez Sejm Ustawodawczy w dniu 22 lipca 1952, Książka i Wiedza, Warszawa 1976, s. 17, 44.

${ }^{2}$ J. Chumiński, Mentalne bariery rozwoju gospodarczego PRL [w:] Modernizacja czy pozorna modernizacja. Społeczno-ekonomiczny bilans PRL 1944-1989, red. J. Chumiński, Wyd. Gajt, Wrocław 2010, s. 112 .

Jędrzej Chumiński wskazuje, że w niektórych branżach ukryte bezrobocie osiągało katastrofalne wręcz rezultaty i w 1989 roku wynosiło np.: w przemyśle węglowym 37,1\%, paliwowym 37,8\%, energetycznym 38,2\%, hutnictwie żelaza 33,5\%, spożywczym $47,6 \%$.

${ }^{3}$ E. Dunn, Prywatyzując Polskę. O bobofrutach, wielkim biznesie i restrukturyzacji pracy, Wydawnictwo Krytyki Politycznej, Warszawa 2008, s. 66.

${ }^{4}$ M. Marody, M. Lewicki, Przemiany ideologii pracy [w:] Kultura i gospodarka, red. J. Kochanowicz, M. Marody, Scholar, Warszawa 2010, s. 105.

${ }^{5}$ Ibidem.
} 
Czesankowej „Merinotex” w Toruniu. W tym przedsiębiorstwie porzucenia pracy w miesiącach letnich sięgały co tydzień 150-160 osób. Odnotowaną sytuację dział kadr tego zakładu usprawiedliwiał tym, że załoga przedsiębiorstwa jest młoda kobiety w wieku około 22. lat, a dla tych osób ważniejszy od zachowania miejsca pracy był letni, przedłużony, wypoczynek.

Zła organizacja pracy, fatalne zarządzanie pracą i niedostateczne wykorzystanie kwalifikacji pracownika wywoływały pomruki niezadowolenia, głównie ze strony starszych, doświadczonych w latach II Rzeczypospolitej i okresie okupacji hitlerowskiej, pracowników. W Zakładach Naprawczych Taboru Kolejowego w Bydgoszczy odnotowano następującą sytuację:

W rozmowach robotnicy wracaja do czasów okupacyjnych podkreślając sprawna organizację dostaw materiałowych i organizację pracy. Jeden z pracowników tendrowni bez większego entuzjazmu opowiadat o tym jak pracowat przy rozbudowie kotlarni. Stwierdzat, że Aufsehera prawie nie byto widać, on sam z calówka chodzit po placu budowy, wybierat materiat jaki byt potrzebny, przycinat, zbijat i robota szła nad podziw sprawnie. Teraz z materiatem nieraz żmudzi kilka godzin, szukając zmęczy się więcej niż robota przez cały dzień. Dostownie nie mieści mu się w głowie, że można stworzyć taki bałagan przez 16 lat po wojnie, w porównaniu z porzadkiem, jaki panowat w zakladzie w latach wojny ${ }^{6}$.

Stałym rytuałem codziennej realizacji pracy, jak odnotowała Małgorzata Mazurek, w Zakładach im. Róży Luksemburg w Warszawie ${ }^{7}$ była improwizacja, obejmująca organizację pracy i produkcji. Marnotrawstwo czasu pracowników i przede wszystkim energii ludzkiej w czasie godzin pracy, brak stałego rytmu pracy, powodowało frustrację pracowników, prowokowało wręcz do patologicznych zachowań np. spożywanie alkoholu w miejscu pracy, kradzieże i w konsekwencji obniżało się morale pracownika.

Motywującą rolę w zakresie podnoszenia produktywności pracowników w gospodarce socjalistycznej utraciła płaca. Podążając za poglądem Ludwiga von Misesa, należy odnotować że:

w kapitalistycznym porzadku społecznym pracownikowi przypada produkt jego pracy (...). Sam pracownik jest więc zainteresowany tym, by produktywność świadczonej przez niego pracy była możliwie najwyższa. Natomiast w socjalistycznym porządku społecznym nie może powstać jakikolwiek związek pomiędzy wydajnościa pracy a wynagrodzeniem. Wszystkie próby ustalenia wktadu pracy i ustalenia na tej podstawie wysokości wynagrodzenia musiaty ponieść klęskę ze względu na niemożliwość obliczenia produktywnego wkładu pojedynczych czynników produkcji ${ }^{8}$.

W roku 1979, w jednym z przedsiębiorstw w Bydgoszczy, w związku z wprowadzoną podwyżką płac wystąpił konflikt, którego podłoże doskonale oddaje następująca notatka:

\footnotetext{
${ }^{6}$ Instytut Pamięci Narodowej w Bydgoszczy (dalej cyt.: IPN Bydgoszcz), sygn. IPN By 069/1283 t. 7 „Naprawa”, Meldunek dotyczący sytuacji w zakładzie ZNTK, 3.03.1959 r.

${ }^{7}$ M. Mazurek, Socjalistyczny zakład pracy. Porównanie fabrycznej codzienności w PRL i NRD u progu lat sześćdziesiątych, Trio, Warszawa 2005, s. 188.

${ }^{8}$ L. von Mises, Socjalizm, Arcana, Kraków 2009, s. 138-139.
} 
Duże rozgoryczenie powoduje to, że dokonywane jest to [podział pieniędzy na podwyżki-S.K.] w sposób wyłacznie mechaniczny, a nie wedtug zastug $i$ wkładu pracy. W opinii pracowników, szczególnie umystowych majacych określone zdanie na temat jakości pracy swoich podwładnych, podwyżki dla niektórych nie powinny w ogóle mieć miejsca. Wocenie wielu pracowników jest to wręcz demoralizujace i zniechęcajace do pracy ${ }^{9}$.

Sytuacja, którą obserwowano była naturalną konsekwencją tego, że ciężar pracy w państwowych przedsiębiorstwach był przypisany do etatu, który stworzono w fabryce i nie miał on żadnego związku z wyceną indywidualnego wysiłku, wkładu osobistego i zaangażowania pracownika w pracę ${ }^{10}$.

Konflikty na tle płacowym wybuchały praktycznie w każdym zakładzie pracy, a robotnicy wymuszając wzrost płac posługiwali się, jak się okazywało, skutecznym orężem w postaci, ponoć nieobecnego w socjalistycznym przedsiębiorstwie, strajku. Już tylko jego zapowiedź zmuszała kierownictwo przedsiębiorstwa do ustępstw i wyrażenia zgody na postulaty robotników. W Bydgoszczy, w Zakładach Naprawczych Taboru Kolejowego w połowie 1978 roku, groźba wybuchu strajku na tle sporu o wysokość wypłaconych poborów sprawiła, że Komitet Wojewódzki Polskiej Zjednoczonej Partii Robotniczej uregulowat tę kwestie [płac - S.K.] - zapewniono pracowników, że z powodu braku materiałów nie będa mieć zaniżonych zarobków ${ }^{11}$. W rezultacie cyklicznie powtarzających się sytuacji pogłębiało się u pracowników państwowych przedsiębiorstw przekonanie o tym, że nie ma żadnego związku pomiędzy wysiłkiem indywidualnym, rodzajem wykonywanej pracy, a wysokością miesięcznych poborów. Elementy te były od siebie mocno odległe. Cytowany Ludwig von Mises stwierdził, że [j]eśli nie ma zwiąku między owocami pracy $i$ dochodem pracownika, co ma miejsce $w$ spoteczności socjalistycznej, jednostka będzie zawsze pracować w przeświadczeniu, że nałożono na nia zbyt dużo pracy ${ }^{12}$. W następstwie tego akordowy system pracy jako sposób organizacji produkcji w przedsiębiorstwie się nie sprawdzał. Jak zauważa Małgorzata Mazurek, jedną z przyczyn niskiej wydajności pracy w Polsce Ludowej było tzw. „wychodzenie na swoje”, czyli kalkulowanie przez pracownika indywidualnego wysiłku przy pracy w ten sposób, aby osiągać wyniki przynoszące dochód i nie prowokować przy tym podnoszenia norm pracy ${ }^{13}$. Empiryczne doświadczenia udowodniły, że podniesienie norm pracy w 1966 roku w Zakładach Wytwórczych Sprzętu Teletechnicznego Telkom-Telfa w Bydgoszczy poprzez wprowadzenie tzw. norm technicznie uzasadnionych, sprowokowało falę porzucania pracy. Było to na tyle dokuczliwe dla tego zakładu, że ówczesna prasa nazwała to zjawisko „kataklizmem na miarę długoterminowego strajku” ${ }^{14}$. Określenie to było w pełni uzasadnione, ponieważ zrezygnowało z pracy, według informacji źró-

\footnotetext{
${ }^{9}$ IPN Bydgoszcz, „Polietylen”, Meldunek operacyjny z dnia 14.04.1979 roku, sygn. IPN By 044/986.

${ }^{10}$ M. Marody, M. Lewicki, op. cit., s. 108.

${ }^{11}$ IPN Bydgoszcz, t. 1 „Naprawa”, Uzupełniania analiz, sygn. IPN By 069/1283.

${ }^{12}$ L. von Mises, op. cit, s. 138.

${ }^{13}$ M. Mazurek, op. cit., s. 205.

${ }^{14}$ Jan Rem (Jerzy Urban), Zapotrzebowanie na pomyst, „Życie Gospodarcze” 1966, nr 25.
} 
dłowych, od 50 do 70\% załogi. Rezygnujący z pracy pracownicy jako przyczynę podjęcia tej decyzji podawali zbyt wysokie normy, które trzeba było wypracować w ciągu dnia roboczego.

Motywacyjny charakter utraciła nawet trudna do zmierzenia satysfakcja z wykonywanej pracy. W Grudziądzu, w Fabryce Maszyn Rolniczych „Agromet-Unia” w 1979 roku dziennikarz „Przeglądu Technicznego” odnotował następujący obraz:

na pierwszym stanowisku sterta dtugich, szerokich płaskowników. Produkty huty Zawiercie. Co drugi krzywy. Wktada się go pod prasę, tnaca prostokaty lemieszy. Co drugi lub trzeci trzeba odrzucać. Nie można zwrócić hucie tego szmelcu? Można. Powołać komisję, napisać pisma itp. Tylko nic z tego nie wynika. Zdenerwowani telewizyjnymi obrazkami o sukcesach huty, robotnicy przyszli do fabrycznego Komitetu Partyjnego: jak oni sa tacy dobrzy, to dlaczego my otrzymujemy taki kiepski materiat. Oni wykonuja plan - my mamy przestoje i nie zarabiamy ${ }^{15}$.

Zastana rzeczywistość zniechęcała do emocjonalnego zaangażowania się w pracę. System gospodarki niedoborów gwarantował bowiem, że niskiej jakości produkty zawsze znalazły nabywcę. Kierownictwo Fabryki Akcesoriów Meblowych w Chełmnie zwracało uwagę, że: [p]roblem jakości w przedsiębiorstwie jest trudny do oceny z uwagi na wysoki deficyt okuć, który powoduje, że wyroby o obniżonym, $w$ stosunku do normatywów standardzie, sa zbywane na rzecz spółdzielni i przemystu terenowego ${ }^{16}$.

Praca w Polsce Ludowej była mało satysfakcjonująca. Stąd już tylko wystarczyło wykonanie kroku w kierunku nadużyć w pracy. Zjawisko to było nagminne. Co więcej, nieetyczna postawa wobec państwowego pracodawcy, była zazwyczaj utożsamiana z zaradnością życiową. Dowodzi tego informacja z czerwca 1979 roku:

Nie do mnie należy ocena pracy innych ludzi, organizacja pracy $i$ wszystkie metody kierownictwa. Zdaniem wielu to niedolęstwo, kumoterstwo, wspólzależność $i$ bałagan. Trzy czwarte ludzi żyje z innej pracy $-w$ godzinach pracy $w$ zakładzie. Dużo nie robi nic. Każdy patrzy przez palce na sprawki drugiego. Od czasu do czasu przypuszczaja szturm na dyscypline pracy i inne glupstwa. Jakby to byto ważne o której przychodzi, a nie to, co robi w ciagu dnia pracy. Niektórzy kierownicy zależni są od pracowników, względnie przymykają oczy z innych względów ${ }^{17}$.

System nieformalnych kontaktów między pracownikami wykreował skomplikowaną sieć znajomości i zależności. Jego materialną formą było zjawisko świadczenia podwójnej pracy, czyli tej na użytek państwowego zakładu pracy, i tej wynikającej z zaradności i przedsiębiorczości pracownika. Pozwalał on, z jednej strony na czerpanie satysfakcji indywidualnej z wykonanej „,na boku” pracy, z drugiej, był czynnikiem demoralizującym. Aspekt ten w następujący sposób skomentowała Elizabeth Dunn:

\footnotetext{
15 J. Stępowski, Jak UFO, „Przegląd Techniczny” 1979, nr 14.

${ }^{16}$ Archiwum Państwowe w Toruniu, Fabryka Akcesoriów Meblowych w Chełmnie, Analiza gospodarcza, sygn. 250.

${ }^{17}$ IPN Bydgoszcz, „Polietylen”, sygn. IPN By 044/986.
} 
Innym przykładem były znajomości w zakładzie pracy, które ułatwiały wynoszenie z fabryki różnych rzeczy dla prywatnych potrzeb. Dobre uktady między pracownikami Alimy i strażikami przy bramie pozwalaty szmuglować na zewnatrz produkty, surowce, a nawet przedmioty, które robotnicy wykonali na użytek osobisty $w$ godzinach pracy $i$ z zakładowych materiałó $w^{18}$.

\section{Praca w Polsce po 1989 roku}

Wprowadzenie głębokich reform w Polsce zapowiedział 24 sierpnia 1989 roku ówczesny Prezes Rady Ministrów, Tadeusz Mazowiecki. W wygłoszonym w sejmie wystąpieniu programowym mówił, że [t]rzeba przywrócić w Polsce mechanizmy normalnego życia politycznego. Przejście jest trudne, ale nie musi powodować wstrzasów. Przeciwnie - będzie droga do normalności. W kolejnych zdaniach Premier zapowiadał: Musi ulec zmianie dotychczasowa filozofia państwa. Nie może ono zajmować się wszystkim i wszystkiego gwarantować. Powinno ułatwiać i regulować działalność. Główna myśl reform, jakie zamierzano przeprowadzić w rozchwianym, a odziedziczonym po Polsce Ludowej systemie gospodarczym sprowadzała się do zmiany dotychczasowej roli państwa w gospodarce. Państwo nie chciało być właścicielem prawie wszystkich środków produkcji. W tym strategicznym celu zawarta była geneza odwrócenia proporcji własności. Zaproponowano stopniowe ograniczenie roli państwa $\mathrm{w}$ gospodarce, a zwiększanie roli prywatnych przedsiębiorców i stymulowanie postaw przedsiębiorczych. Prezes Rady Ministrów zapowiadał: Dlugofalowym strategicznym celem poczynań rządu będzie przywrócenie $w$ Polsce instytucji gospodarczych od dawna znanych i sprawdzonych. Rozumiem przez to powrót do gospodarki rynkowej oraz roli państwa zbliżonej do rozwiniętych gospodarczo krajów. Polski nie stać już na ideologiczne eksperymenty. Tym samym zmieniła się rola pracodawcy i pracobiorcy. T. Mazowiecki zwracał uwagę, że: Potrzebujemy takich mechanizmów prawnych i ekonomicznych, które dadza ludziom przedsiębiorczym poczucie bezpieczeństwa dla ich działalności i pozwola wszystkim odnaleźć moralny i materialny sens pracy. Leszek Balcerowicz w grudniu 1989 roku uściślił wypowiedź Mazowieckiego dodając, że [t]rzeba skończyć z fatszywa gra, w której ludzie udaja, ze pracuja, a państwo udaje, że płaci. Zapowiadał przy tym, że [a]lternatywa, która proponujemy, to życie udane, zamiast udawanego. W myśl tych słów praca przestała być, jak stanowiła Konstytucja PRL z 1952 roku, obowiązkiem, a miała stać się źródłem satysfakcji obywateli, dzięki prawu do swobodnego wyboru miejsca pracy. Powstał rynek pracy, a miarą wartości pracownika miały stać się jego kwalifikacje, umiejętności i doświadczenie.

Radykalne reformy gospodarcze realizowane w Polsce stały się bezpośrednią przyczyną podziału społeczeństwa polskiego na dwie grupy: beneficjentów reform, którzy ten czas wykorzystali na założenie własnej firmy, a dzięki zmysłowi przedsiębiorczości bogacili się, i osoby pokrzywdzone, które żyły w poczuciu zagrożenia utratą pracy. Mirosława Marody i Mikołaj Lewicki na podstawie wyników badań

\footnotetext{
${ }^{18}$ E. Dunn, op. cit., s. 143.
} 
z 1994 roku podali, że Polacy w pierwszym okresie transformacji gospodarczej zwracali przede wszystkim uwagę na indywidualne przymioty człowieka. Ceniono jego zdolności, ambicję, sumienną pracę, wykształcenie. Obok tych cech za przejaw zaradności życiowej uznawano, podobnie jak w Polsce Ludowej, cwaniactwo i spryt, dobre znajomości, szczęśliwy przypadek, powiązania polityczne ${ }^{19}$. Autorzy tych badań podkreślają przy tym, że wymienione cechy były bardzo mocno ze sobą skorelowane i w następstwie tego w świadomości Polaków zakorzenione były dwie, całkowicie odmienne drogi, które prowadziły do sukcesu jednostki: uczciwa praca i przedsiębiorczość oraz spryt i dobre znajomości.

Bezpośrednim skutkiem prywatyzacji i restrukturyzacji przedsiębiorstw zapoczątkowanej w 1989 roku, dla wielu pracowników, było nowe doświadczenie pracy. Duża grupa pracowników tych przedsiębiorstw czuła się rozgoryczona mikroekonomicznymi efektami reform gospodarczych. W ich odczuciu państwo rękoma tzw. reformatorów niszczyło dorobek industrialny powojennego pokolenia, które wyrzekało się dobrobytu w imię tego, aby jego dzieci żyły lepiej. Tymczasem zbudowane przez to pokolenie przedsiębiorstwa bankrutowały, a ich majątek był wyprzedawany. Ta postawa znalazła wyraz w liście z grudnia 1999 roku pracowników Zakładów Mięsnych w Nakle nad Notecią skierowanym do Redaktor programu „Sprawa dla reportera" Elżbiety Jaworowicz ${ }^{20}$. Pismo to oddaje ówczesne emocje: Następuje dewastacja zatrzymanych od listopada [1999 roku - S.K.] zakładów i wyprzedaż jego wyposażenia (nawet prawie nowego) bezmyślnie na złom, aby tylko pan syndyk miat swoje wynagrodzenie. Pracownicy podają, że spotkanie z syndykiem i wojewodą kujawskopomorskim, które odbyło się 23 grudnia 1999 roku ostatecznie nas załamało. W akcie rozpaczy napisano: To co się dzieje, to bezprawie, nie liczenie się z interesem zaktadu, gminy, powiatu i w ogóle nas - maluczkich. Nikt się z nami nie liczy, a szczególnie obecny syndyk, którego utrzymanie przez trzy lata pochtonęło też bardzo duże pieniq$d z e$. Ton listu, emocje w nim zawarte, to informacja o tym, że w społeczeństwie nastąpiło wyraźne rozwarstwienie na „maluczkich”, czyli dyskryminowanych obywateli, na potrzeby których nikt, w tym rządzący, nie zwracają uwagi, oraz na pozostałych, czyli osoby zadowolone z reform. Celowe użycie pojęcia „maluczkich” wzmacnia przekaz i odsłania beznadziejną sytuację mieszkańców polskiej prowincji. Bezsilność w złości oddaje kolejny fragment tego listu: To przeklęte koto niemocy należy szybko przerwać, zamknięty na głucho zakład niszczeje, kilkunastostopniowy mróz może tym razem dokonać takich spustoszeń, że już go nie uruchomimy.

Praca stawała się, szczególnie w obszarach polski powiatowej, dobrem pożądanym, a niedostępnym dla wielu. Byli pracownicy takich firm, jak Zakłady Mięsne w Nakle nad Notecią, w zasadzie nie posiadali wysokich kwalifikacji zawodowych, związani byli często w swoim życiu zawodowym z jednym zakładem pracy i czuli się, w momencie bankructwa ich zakładu, oszukani. $Z$ ekonomicznego punktu widzenia i racjonalności gospodarowania bankructwo przedsiębiorstwa było i jest naturalne,

\footnotetext{
${ }^{19}$ M. Marody, M. Lewicki, op. cit., s. 110.

${ }^{20}$ Archiwum Kujawsko Pomorskiego Urzędu Wojewódzkiego w Bydgoszczy, Wydział Rozwoju Gospodarczego i Przekształceń Własnościowych, List z dnia 10 stycznia 2000 roku Pracowników Zakładów Mięsnych w Nakle nad Noteciq do Elżbiety Jaworowicz, Redaktor programu „Sprawa dla reportera”, sygn. 1733/24.
} 
wpisane w system gospodarki rynkowej. Trudność w tym wypadku polegała jednak na tym, że bankructwa dotykały ludzi, którzy doświadczenie zawodowe i kwalifikacje zawodowe zdobywali w zaprogramowanym sztucznie systemie gospodarczym. Dla tych osób wolny rynek i jego bezwzględne prawa oznaczał zniszczenie świata, który budowali przez lata. Stąd rodził się dramatyczny apel do władz lokalnych i dziennikarzy: Jest nowy chętny na kupno całości (złożyl ofertę $i$ wpłacił wadium) i my załoga - chętna do pracy, a nie na kuroniówki. Nakło nad Notecia jest już rejonem o szczególnym zagrożeniu bezrobociem, a my nie chcielibyśmy tej rzeszy jeszcze powiększać. W konkluzji listu padło stwierdzenie: My wierzymy w moc Pani programów, tu u nas musi się nam to razem udać!

Rozgoryczenie, rozpacz, bezsilność wobec machiny reform - tak można w skrócie określić nastrój społeczny, który oddaje cytowany powyżej list. Dodatkowo, zdaniem Krzysztofa Jasieckiego, zaobserwowano w Polsce słabszą niż na Zachodzie pozycję pracowników, wynikającą głównie $\mathrm{z}$ wysokiej stopy bezrobocia ${ }^{21}$, które było skutkiem likwidacji przerostów zatrudnienia w okresie Polski Ludowej. Wysokie bezrobocie dawało przewagę pracodawcy na rynku pracy. Pracodawca stał się osobą dyktującą warunki pracy. Wartość rynkową wielu pracowników obniżały ich niskie kwalifikacje zawodowe, które wynieśli z okresu Polski Ludowej. Wskazane czynniki wpłynęły na pogorszenie warunków pracy, szczególnie na polskiej prowincji. Cytowany K. Jasiecki zwrócił uwagę, że zaobserwowano niechęć pracodawców do zawierania umów zbiorowych i do tworzenia reprezentacji pracowniczych, przewagę paternalistycznego lub autorytarnego stylu rządzenia oraz przekształcenie stosunków pracy w nieformalne i zindywidualizowane relacje osłabiające podmiotowość klas pracowniczych. Wprowadzone zostały regulacje stosunków pracy pomniejszające znaczenie prawa i formalnych umów, które zastępuje $w$ rosnacym zakresie prymat ekonomii i optymalizacji finansowej ${ }^{22}$. Rodzimych przedsiębiorców utwierdzają w przekonaniu o tym, że zorganizowany w ten sposób rynek pracy jest rozwiązaniem optymalnym, opinie międzynarodowych ekspertów. Mitchell A. Orenstein zadając pytanie ,Jak wysoko poleci Polska?" odpowiedział, że Polska musi dziś utrzymywać niski poziom wynagrodzeń, żeby przyciagnać zagraniczne firmy i zachować konkurencyjność. Cytowany autor zauważa przy tym, że aspiracje Polaków rosna. Co dalej? ${ }^{23}$. Argumentuje, że atut Polski w postaci niskich płac daje jej gwarancję rozwoju:

Polska powinna mieć na uwadze ten dylemat, gdyż w jej pobliżu znajduja się inne kraje, które mogłyby postużyć jako baza produkcyjna. Kiedy w 2009 roku Dell przenióst europejska fabryke z Limerick w Irlandii do Lodzi, burmistrz Limerick złośliwie zapowiadat, że Dell zapewne za kilka lat przeniesie się na Ukrainę. Można by to samo powiedzieć o wielu call center, centrach obstugi telefonicznej, które stały się filarami zatrudnienia $w$ Polsce ${ }^{24}$.

\footnotetext{
${ }^{21}$ K. Jasiecki, Kapitalizm po polsku. Między modernizacja a peryferiami Unii Europejskiej, Wyd. IFiS PAN, Warszawa 2013, s. 329.

${ }^{22}$ Ibidem.

${ }^{23}$ M.A. Orenstein, Jak wysoko poleci Polska?, „Gazeta Wyborcza” 2014, 11-12 stycznia, s. 14.

${ }^{24}$ Ibidem.
} 
Krzysztof Jasiecki zwraca również uwagę, że:

posocjalistyczne stosunki pracy odbiegaja zarówno od modelu rynkowego, jak $i$ koordynacyjnego. Ze względu na odmienny punkt wyjścia, szybka deindustrializację $i$ duże bezrobocie oraz niższy poziom rozwoju gospodarczego i społecznego, stosunki te przybieraja odmienny charakter, nierzadko nasuwajacy skojarzenia ze standardami dzikiego kapitalizmu ${ }^{25}$.

Bycie pracobiorcą na tak skonstruowanym rynku pracy, wspieranym argumentami natury ekonomicznej i politycznej przez autorytety świata nauki i polityki, jest trudne. Jeśli przy tym kwalifikacje zawodowe pracownika są niskie, może być on skazany na: „mrok w szwalni”. Artykuł Beaty Bialik pod takim tytułem ukazał się w październiku 2014 roku w periodyku „Wysokie Obcasy”, dodatku do „Gazety Wyborczej"'26. Autorka opisując zakład pracy podaje: $w$ hali jest goraco, klimatyzacja nie działa. $Z$ dachu się leje, stanowiska pracy sq nieoświetlone. Lekarz stempluje zdolność do pracy nawet przy chorobie. Pracodawca zalega ze składkami zusowskimi. Paternalistyczne stosunki pracy w tym zakładzie pracy, znajdującym się w powiatowym mieście, oddaje kolejny opis: Czasami trzeba zostać po godzinach. I o tym dowiadujemy się pod koniec pracy. Jeśli ktoś nie chce się zgodzić to sa krzyki. Człowiek się nie liczy, tylko praca ${ }^{27}$. W dalszej części cytowanego tekstu autorka odnotowała: na co dzień majstrowa i brygadzistki przechadzaja się pomiędzy szyjącymi i wydaja polecenia, patrza na ręce: Nie gadać!, Pracować!, Pospiesz się!, czasem komentują wyjście do tazienki. Ten obraz świadczenia pracy potwierdzający paternalistyczną perspektywę pracodawcy wobec pracobiorcy, prezes spółki Trend Fashion postrzega w następujący sposób:

Proszę zauważyć, że Polska w ciagu ostatnich lat przestała być konkurencyjna cenowo nawet w porównaniu z Portugalią. A prace szyjących pań w głównej mierze wycenia rynek, a nie zarząd spótki. To właśnie w naszej branży mamy największa presję, a ceny przeszyć z uwagi na konkurencję azjatycka, ale również europejska. Dwa razy droższy od naszych rodzimych marek Boss już dawno wyszedt do tańszej Turcji, Ahlers, dystrybutor marki Pierre Cardin, szyje w Bośni, a przecież te firmy szyty kiedyś swoje kolekcje w Polsce. Powstaje pytanie, czy naprawde chcemy, aby Vistula, Bytom i inni 100 procent swojej produkcji lokowali za granica ${ }^{28}$.

Argumenty, którymi posługują się współcześni menedżerowie i pracownicy, ukazują ugruntowaną i silną pozycję pracodawcy na rynku pracy, a to nie sprzyja podmiotowemu traktowaniu pracowników i wpływa na fatalny stan psychiczny wielu z pracobiorców ${ }^{29}$.

Na pogorszenie stosunków pracy w wielu małych, położonych w powiatowych miastach, zakładach pracy wpływa również brak partycypacji załogi w zarządzaniu,

\footnotetext{
${ }^{25}$ K. Jasiecki, op. cit., s. 329.

${ }^{26}$ B. Bialik, Mrok w szwalni, ,Wysokie Obcasy Wyborcza” 2014, nr 42 (801), s. 12.

${ }^{27}$ Ibidem, s. 14.

${ }^{28}$ Ibidem, s. 16.

${ }^{29}$ K. Jasiecki, op. cit., s. 337.
} 
we współuczestniczeniu w podejmowaniu decyzji, dyskusji o czasie pracy czy regulacji płac. $Z$ tego dialogu zostały, co zauważył K. Jasiecki, wypchnięte związki zawodowe i inne organizacje reprezentujące pracowników. Przyczyny tego faktu upatruje się w niskiej świadomości własnego statusu i praw dużej części społeczeń$s t w a^{30}$. Ta sytuacja uprawnia pracodawcę do stwierdzenia, że działacz związkowy destrukcyjnie wpływa na wszelkie formy dialogu między stronami ${ }^{31}$. Powstałą nierównowagę na rynku pracy i przez to rosnącą przewagę przedsiębiorców określa wypowiedź z grudnia 2013 roku Prezesa Związku Przedsiębiorców i Pracodawców, który odnosząc się do postulatu zwiększenia płacy minimalnej powiedział: Przedsiębiorcy maja to $w$ dupie, najwyżej zaczniemy zatrudniać na czarno ${ }^{32}$. W podobnym tonie utrzymana była wypowiedź skierowana do szefa „Solidarności”: może nam pan na warsztat skoczyci3.

Zdaniem Janusza Hryniewicza, w polskiej kulturze prowadzenia biznesu dominuje syndrom „kultury folwarcznej”. Jej egzemplifikacją jest przyjęta norma, że polski szef ma zawsze racje, a wszelkie dopytywania pracownika traktuje on jako podważanie autorytetu $i a_{a t a k^{34}}$. J. Hryniewicz stwierdza, że zmieni się ta kultura dopiero wówczas, gdy kilka pokoleń odejdzie. „Kod folwarczny”, co nie ulega wątpliwości, jest źródłem wolniejszego rozwoju polskiej innowacyjności i przedsiębiorczości, ponieważ zdaniem Hryniewicza $w$ nowoczesnym świecie [my Polacy S.K.] zużywamy na tyle dużo energii, że wystarcza jej zaledwie na pracę. Na innowacje i rozwój już brakuje $e^{35}$. Siły trafności powyższego stwierdzenia dowodzą niezliczone przykłady informujące o świadczeniu pracy w polskich firmach.

Brak partycypacji pracowników w zarządzaniu firmą odnotowuje się również w dużych korporacjach. Informacje te pośrednio można zaczerpnąć z forów internetowych, na których pracobiorcy oceniają pracodawców. Brak dialogu wewnątrz firmy oddaje następujący wpis:

Uważam, że kierownicy i pion personalny powinni bardziej zadbać o ludzi wewnątrz organizacji, jeśli tego nie zrobia, może się okazać, że KP straci wielu najbardziej zaangażowanych specjalistów, którzy sa zmuszeni odejść, bo nie ma dla nich żadnych możliwości rozwoju z jednej prostej przyczyny - z uwagi na ciężka prace zostali zaszufladkowani jako wyrobnicy, a nie osoby z potencjatem ${ }^{36}$.

Niedostatecznie wytyczone ścieżki dialogu pracodawcy z całą załogą i jej reprezentacją zajęły w firmach rozmowy i negocjacje indywidualnie prowadzone z pracownikami. Kultura indywidualizmu zdominowała wiele firm. Pracobiorcy potwierdzają to $\mathrm{w}$ swoich uwagach: Z perspektywy pracownika AMS robi dobre

\footnotetext{
${ }^{30}$ Ibidem, s. 329.

${ }^{31}$ B. Bialik, op. cit. s. 16.

${ }^{32}$ Co siedzi w głowie polskiego bogacza, z prof. Krzysztofem Jasieckim rozmawia Grzegorz Sroczyński, „Gazeta Wyborcza” 2013, 24-26 grudnia, s. 25.

${ }^{33}$ Ibidem, s. 25.

${ }^{34}$ A. Kowalik, Folwark biurowy, „Forbes” 2014, nr 07 (lipiec), s. 120-122.

${ }^{35}$ Ibidem, s. 122.

${ }^{36}$ www.golednlinie.pl/firma/kompaniapiwowarska/ocena (data dostępu: 27.03.2015).
} 
wrażenie. Można wynegocjować sensowne wynagrodzenie, podejście do pracownika jest poprawne, godziny pracy elastyczne, przyjazna atmosfera, możliwość pracy $z$ dоти ${ }^{37}$. Wielu pracobiorców zwraca uwagę również na fakt, że często dia$\log \mathrm{z}$ pojedynczym pracownikiem ulega w firmie zaburzeniom: Przydałoby się wprowadzić system motywacji oparty na budowaniu dobrych relacji z pracownikami oraz wprowadzić ułatwienia dla przedsiębiorczych pracowników, którzy maja innowacyjne pomysty ${ }^{38}$. Inna wypowiedź ujęła ten problem w następujący sposób: Pracodawca dobry na poczatek, słabe zarobki w porównaniu z innymi korporacjami, staby system motywacji stałych pracowników - bardzo niskie podwyżki, o które trzeba się prosić, duża rotacja pracowników... ${ }^{39}$.

Wydaje się, że indywidualna ocena każdego pracownika przez pracodawcę oraz brak partycypacji załogi w zarządzaniu fabryką nie przeszkadza wielu pracobiorcom. Na portalach internetowych zwracają oni uwagę na to, że firmy dają zatrudnionym w nich pracownikom możliwość rozwoju indywidualnego: Wspaniałe HR, cudowni, mili i pomocni ludzie, duże możliwości nauki, zwłaszcza dla osób zaczynajacych kariere w HR BPO ${ }^{40}$.

W Polsce obok kultury indywidualizmu, w firmach utworzonych na bazie kapitału niemieckiego, pojawiła się kultura biznesu, którą określa się mianem kolektywizmu. Ten styl zarządzania oddają wpisy na portalach internetowych:

\begin{abstract}
Z pewnościa jest to firma, w której warto się wykazać; inicjatywa jest zauważalna i premiowana. Wysoka kultura błędów - lepiej się przyznać i zapobiegać kolejnym. Jest miejsce na to, by próbować coś zmienić; jest tez miejsce na kreatywność. (...) Silna hierarchia, choć stawia się na partnerskie relacje góra-dól, oparte na autorytecie wiedzy i doświadczenia. Duże możliwości rozwoju dla zdolnych i ambitnych, a średniacy maja ciepetko ${ }^{41}$.
\end{abstract}

Podkreśla się również, przy firmach zarządzanych zgodnie z zasadami kultury kolektywizmu, że są to przedsiębiorstwa dla ludzi szukających stabilności. Podobne oceny zyskuje inna firma zbudowana na kulturze kolektywizmu: Praca wymagająca, ale przy odpowiednim nastawieniu daje satysfakcję. Jasno wyznaczone i mierzalne cele. Mogłoby być trochę więcej możliwości rozwoju, jednak pracuje się tam tak dobrze... ${ }^{42}$. Inny wpis odnoszący się do tej samej firmy: Nie zmieniajcie tej firmy na sitę. Pozwólcie, aby nadal ludzie mieli możliwość awansu, pozwoli to wykształcić dobrych fachowców ${ }^{43}$.

Rynek pracy miast powiatowych i małych miasteczek rządzi się nieco innymi prawami niż ten w wielkich miastach. Doświadczają tego lokalni pracodawcy, którzy są szanowanymi obywatelami społeczności lokalnej, gdy zatrudniają pracowników i utrzymują stabilne zatrudnienie. Gdy zmienia się koniunktura rynkowa i pojawia się

\footnotetext{
${ }^{37}$ www.goldenlinie.pl/firma/alexander-mann-solutions-polska/ocena/ (data dostępu: 27.03.2015).

${ }^{38}$ Ibidem.

${ }^{39}$ Ibidem.

${ }^{40}$ Ibidem.

${ }^{41}$ www.golednlinie.pl/firma/volkswagen-poznan/ocena/ (data dostępu: 27.03.2015).

${ }^{42}$ www.goldenlinie.pl/firma/nivea/ocena/ (data dostępu: 27.03.2015).

${ }^{43}$ Ibidem.
} 
problem z nadmiarem siły roboczej w firmie, co pociąga za sobą konieczność redukcji zatrudnienia, ta decyzja wywołuje agresję lokalnego środowiska. Doświadczył tego Zbigniew Sosnowski, właściciel firmy Kross z Przasnysza. Sosnowski, największy lokalny pracodawca i chluba Przasnysza, w jednej chwili stat się wrogiem publicznym - Znienawidzono mnie w mieście - przyznaje $e^{44}$. Właściciel firmy wskazuje, że zwalniając ludzi starał się kierować zasadami etycznymi: Jeśli miałem zwolnić naprawdę dobrego fachowca, którego żona miała prace w mieście, albo jedynego żywiciela rodziny, zwalniatem tego pierwszego... ${ }^{45}$. W dalszej wypowiedzi stwierdza: Takie sq konsekwencje prowadzenia biznesu. To nie zabawa, to odpowiedzialność.

Rolę menedżera i właściciela przedsiębiorstwa, w kierowaniu i organizowaniu pracy dla osób, które zatrudnia, właściciel marki CCC Dariusz Miłek postrzega w następujący sposób: Menedżer, który nie potrafi wymagać, za bardzo wchodzi w relacje z podwtadnymi, nie jest dobrym menedżerem. Trzeba z ludzi wyciskać robote, inaczej wszystko się rozsypie. Komentując pojęcie „wyciskać robotę” D. Miłek precyzuje: Ostatnio na przykład musiałem zwolnić z dyrektorskich stanowisk swoich kolegów jeszcze z czasów kolarstwa. W firmie zostało to przyjęte z dużym zaskoczeniem, bo niektórzy myśleli, że oni sq nietykalni. Ale za to kiedy sq wyniki, ludzie sq naprawdę dobrze wynagradzani ${ }^{46}$. Wskazane ,wyciskanie roboty” z pracowników jest podstawowym źródłem stresu dla osób pracujących w wielu firmach. Pracujący skarżą się na portalach internetowych, przede wszystkim na stres związany z wykonywaniem powierzonych im obowiązków: „dużo zadań, mało czasu”, „czasami za dużo wrażeń" ${ }^{47}$, „stres, zbyt wiele zadań” ${ }^{4}$, „praca dla ludzi, którzy mogą poświęcić swój czas prywatny, duży zakres obowiązków, praca niestabilna, ciągłe zmiany" 49 lub bardziej wyrozumiale: „,czasem stres, ale stres jest w każdej pracy”, ,czasami nadgodziny (ale pokażcie firmę, gdzie nie ma nadgodzin)" ${ }^{50}$. Pracownicy zauważają także błędy w zarządzaniu personelem: ,wyciskanie ostatnich soków z Działu Sprzedaży przy jednoczesnym hołubieniu Działu Marketingu powoduje rozgoryczenie tych pierwszych" 51 lub podają wprost: „,czasami warto zainwestować w pracownika"52. Pracownicy wielu firm odczuwają osamotnienie, zauważają, że ich wysiłek i lojalność wobec pracodawcy pozostają niezauważone. Piszą w związku z tym o ,niejasnym systemie oceny pracowników”53 lub nawet o „demotywujących przełożonych”, którzy prowadzą ,regularne polowania na czarownice" ${ }^{54}$. Zdaniem większości osób zamieszczających wpisy na portalach internetowych, najlepszą formą wyrażenia uznania dla lojalnego i wydajnego pracownika jest gratyfikacja pieniężna lub oferowany pracownikowi bogaty pakiet socjalny.

\footnotetext{
${ }^{44}$ J. Cieński, Od towarzyszy do kapitalistów, Kurhaus Publishing, Warszawa 2014, s. 200.

${ }^{45}$ Ibidem, s. 200.

${ }^{46}$ W biznesie nakręca mnie wyścig, z Dariuszem Miłkiem rozmawiat Piotr Karnaszewski, „Forbes”2015, nr 4 (kwiecień), s. 28.

${ }^{47}$ www.golednlinie.pl/firma/volkswagen-poznan/ocena/ (data dostępu: 27.03.2015).

${ }^{48}$ www.goldelinie.pl/firma/raben/ocena/ (data dostępu: 27.03.2015).

${ }^{49}$ www.goldenline.pl/firma/kompaniapiwowarska/ocena/ (data dostępu: 27.03.2015).

${ }^{50}$ www.goldenlinie.pl/firma/alexander-mann-solutions-polska/ocena/ (data dostępu: 27.03.2015).

${ }^{51}$ www.goldenline.pl/firma/kompaniapiwowarska/ocena/ (data dostępu: 27.03.2015).

${ }^{52}$ www.goldenlinie.pl/firma/press-glass-sa/ocena/ (data dostępu: 27.03.2015).

${ }^{53}$ www.goldenlinie.pl/firma/nivea/ocena/ (data dostępu: 27.03.2015).

${ }^{54}$ www.goldenline.pl/firma/kompaniapiwowarska/ocena/ (data dostępu: 27.03.2015).
} 
$\mathrm{Z}$ nieco innej perspektywy wygląda ocena zadowolenia i satysfakcji z pracy, gdy wypowiada się pracodawca. Praca dla wielu prywatnych przedsiębiorców, często, co istotne ponad siły, mimo wszystkich niedogodności związanych z prowadzeniem firmy, jest dla nich źródłem satysfakcji i realizacji życiowych ambicji. D. Miłek ujął istotę tego problemu w następujący sposób: Teraz w trzy lata chcemy otworzyć jeszcze 500 sklepów o większej powierzchni i podwoić skalę biznesu. To mnie teraz nakręca. To jest jak wyścig, a ja jestem na jednym ze środkowych etapów. I co miatbym powiedzieć potem moim dzieciom? Że mogłem wygrać, ale mi się nie chciało? ${ }^{55}$.

Inny styl zarządzania firmą prezentuje Bydgoski przedsiębiorca z branży cukierniczej, Adam Sowa. Jego filozofia pracy i zarządzania biznesem oparta jest na bezpośrednim kontakcie z pracownikiem. Do codziennej rutyny przeszły wizytacje sali produkcji: od 25 lat tak samo zaczynam każdy dzień, od wizyty na produkcji, gdzie próbuję ciastek ${ }^{56}$. Więź z pracownikami zawiązuje on prosząc, aby nie zwracać się do niego „panie Prezesie”, lecz „panie Adamie”.

Polacy po 1989 roku zaliczają się do narodów zapracowanych. Według danych OECD w 2013 roku Polak przepracował przeciętnie w ciągu całego roku 1918 godzin. W tym samym okresie inne narody Europy pracowały mniej. Mieszkańcy Hiszpanii, Szwecji, Wielkiej Brytanii przepracowali średnio około 1600 godzin, Niemcy 1388 godzin, Francuzi 1489 godzin, a średni czas pracy, według OECD, wynosił w 2013 roku, 1770 godzin $^{57}$.

Czas pracy Polaków zmieniał się. W latach Polski Ludowej średnio każdy Polak pracował o około 100 godzin mniej, niż po 1989 roku. Odnotowuje się przy tym wyraźne różnice sektorowe. Pracownicy zatrudnieni w sektorze publicznym w 2010 roku pracowali średnio 1813 godzin, a w 2012 roku około 1800 godzin, natomiast pracownicy sektora prywatnego w 2010 roku pracowali średnio 2044 godziny, a w 2012 roku - 2028 godzin $^{58}$.

Tabela 1. Średni czas pracy Polaków w latach 1985-1987 i latach 2010-2012

\begin{tabular}{|c|c|c|c|}
\hline \multicolumn{2}{|c|}{ Polska Ludowa } & \multicolumn{2}{c|}{ Rzeczpospolita Polska } \\
\hline Rok & Średni czas pracy w godz. & Rok & Średni czas pracy w godz. \\
\hline 1985 & 1847 & 2010 & 1955 \\
\hline 1986 & 1838 & 2011 & 1945 \\
\hline 1987 & 1844 & 2012 & 1944 \\
\hline
\end{tabular}

Źródło: Rocznik statystyczny 1988 rok, GUS, Warszawa 1989, s. 220; Rocznik statystyczny pracy 2012 rok, GUS, Warszawa 2013, s. 213.

\footnotetext{
${ }^{55}$ W biznesie nakręca mnie..., s. 23.

${ }^{56}$ P. Karnaszewski, Tajemnica stodkiego imperium, „Forbes” 2014, nr 11 (listopad), s. 62.

${ }^{57}$ P. Arak, Polacy: pracoholicy Europy, www.obserwatorfinansowy.pl/tematyka/makroekonomia/pola cy-pracoholicy-europy/ (data dostępu: 01.04.2015).

${ }^{58}$ Rocznik statystyczny pracy 2012 rok, GUS, Warszawa 2013, s. 213.
} 


\section{Zakończenie}

Konkludując, moim zdaniem warto podkreślić to, że etyka pracy, postawa pracownika wobec pracodawcy, zależna jest od ustroju politycznego w danym kraju. W Polsce, w latach Polski Ludowej, rozregulowanie rynku pracy przez wprowadzenie do niego ideologicznych zasad spowodowało, że pojęcie etyki pracy pozostało wyłącznie na stronach publikacji ideologów systemu gospodarki niedoborów. Pracownik otrzymał od państwowego pracodawcy prawo do pracy i obowiązek pracy, oraz ustalane według kryteriów biurokratycznych wynagrodzenie, które było całkowicie niezwiązane z jakością świadczonej pracy i jej wydajnością. To przekładało się na demoralizację osób zatrudnionych i prowadziło do wypaczenia etyki pracy. Przywrócenie w Polsce po 1989 roku wolnego rynku poddało weryfikacji obowiązujące w Polsce Ludowej zasady etyki pracy. Pracodawca oczekuje od pracobiorcy zaangażowania emocjonalnego w wykonywanie pracy, wydajnej pracy i rzetelności. Pracobiorca chciałby, aby pracodawca docenił jego wysiłek, pozwolił mu na awans w firmie, zwiększył jego uposażenie i zorganizował mu pracę $\mathrm{w}$ ten sposób, że praca dla niego stanie się źródłem satysfakcji indywidualnej. Rzeczywistość w wielu przypadkach wyraźnie odstaje od opisanych relacji. Pracobiorca, ze względu na wysokie bezrobocie, zmuszony jest codziennie udowadniać przed pracodawcą to, że jest potrzebny w firmie, godzi się pracować ponad przyjęte normy godzin pracy, obawiając się w przypadku odmowy świadczenia pracy, zwolnienia. Pozycja pracownika, głownie w mniejszych firmach, położonych na prowincji uległa osłabieniu na skutek wyeliminowania z jej przestrzeni związków zawodowych i innych instytucji reprezentujących pracowników. W konsekwencji zanika partycypacja pracowników w zarządzaniu zakładem pracy, a pracodawca jest jedyną osobą, która podejmuje decyzje w sprawie pracownika. Te warunki sprawiły, że praca dla wielu jednostek stała się wyłącznie przymusem ekonomicznym, a nie źródłem satysfakcji. Istotne jest zwrócenie także uwagi na fakt, że ogromny wpływ na zadowolenie pracownika $\mathrm{z}$ zajmowanego w zakładzie pracy stanowiska ma kultura biznesu, która została przyjęta przez firmę. Indywidualizm zmusza jednostkę do nieustannej rywalizacji, kolektywizm, pozwala jej przetrwać w grupie. Nałożenie na wskazane dwie kultury biznesu kodu polskiego, tzw. „kodu folwarcznego”, może sprawić, że ta kultura prowadzenia biznesu w dłuższej perspektywie stanie się dla naszego kraju źródłem zapóźnienia. Konstatacje, że w Polsce należy budować kapitalizm, lecz powinno odrzucać się wszelkie rodzime wynalazki usprawniające ten system gospodarczy, brzmi jak przestroga: kapitalizm tak, polska wersja ustroju kapitalistycznego - nie $e^{59}$.

${ }^{59}$ K. Jasiecki op. cit., s. 336. 


\section{Bibliografia}

Arak P., Polacy: pracoholicy Europy, www.obserwatorfinansowy.pl/tematyka/makroekonomia/polacy-pracoholicy-europy/.

Bialik B., Mrok w szwalni, „Wysokie Obcasy. Wyborcza” 2014, nr 42 (801), s. 12.

Chumiński J., Mentalne bariery rozwoju gospodarczego PRL [w:] Modernizacja czy pozorna modernizacja. Społeczno-ekonomiczny bilans PRL 1944-1989, red. J. Chumiński, Wyd. Gajt, Wrocław 2010.

Cieński J., Od towarzyszy do kapitalistów, Kurhaus Publishing, Warszawa 2014.

Co siedzi w glowie polskiego bogacza, z prof. Krzysztofem Jasieckim rozmawia Grzegorz Sroczyński, „Gazeta Wyborcza” 2013, 24-26 grudnia.

Dunn E., Prywatyzując Polskę. O bobofrutach, wielkim biznesie i restrukturyzacji pracy, Wydawnictwo Krytyki Politycznej, Warszawa 2008.

Jasiecki K., Kapitalizm po polsku. Między modernizacja a peryferiami Unii Europejskiej, Wyd. IFiS PAN, Warszawa 2013.

Karnaszewski P., Tajemnica stodkiego imperium, „Forbes” 2014, nr 11.

Konstytucja Polskiej Rzeczypospolitej Ludowej uchwalona przez Sejm Ustawodawczy w dniu 22 lipca 1952, Warszawa 1976.

Kowalik A., Folwark biurowy, „Forbes” 2014, nr 07.

Marody M., M. Lewicki, Przemiany ideologii pracy [w:] Kultura i gospodarka, red. J. Kochanowicz, M. Marody, Warszawa 2010.

Mazurek M., Socjalistyczny zakład pracy. Porównanie fabrycznej codzienności w PRL i NRD u progu lat sześćdziesiątych, Trio, Warszawa 2005.

Mises L. von, Socjalizm, Arcana, Kraków 2009.

Orenstein M.A., Jak wysoko poleci Polska?, „Gazeta Wyborcza” 2014, 11-12 stycznia.

Rem J. (Urban J.), Zapotrzebowanie na pomyst, „Życie Gospodarcze” 1966, nr 25.

Rocznik statystyczny pracy 2012, GUS, Warszawa 2013.

Stępowski J., Jak UFO, „Przegląd Techniczny” 1979, nr 14.

W biznesie nakręca mnie wyścig, z Dariuszem Miłkiem rozmawiat Piotr Karnaszewski, „Forbes" $2015, \mathrm{nr} 4$.

Instytut Pamięci Narodowej w Bydgoszczy:

„Naprawa”, sygn. IPN By 069/1283 t. 7.

„Polietylen”, sygn. IPN By 044/986

Archiwum Państwowe w Toruniu:

Fabryka Akcesoriów Meblowych w Chełmnie, Analiza gospodarcza, sygn. 250.

Archiwum Kujawsko Pomorskiego Urzędu Wojewódzkiego w Bydgoszczy:

Wydział Rozwoju Gospodarczego i Przekształceń Własnościowych, sygn. 1733/24

www.goldelinie.pl/firma/raben/ocena/

www.goldenlinie.pl/firma/alexander-mann-solutions-polska/ocena/ 
PRACA JAKO OBOWIĄZEK A PRACA JAKO ŹRÓDŁO SATYSFAKCJI...

www.goldenlinie.pl/firma/nivea/ocena/

www.goldenlinie.pl/firma/press-glass-sa/ocena/

www.golednlinie.pl/firma/kompaniapiwowarska/ocena

www.golednlinie.pl/firma/volkswagen-poznan/ocena/ 